\title{
DINAMIKA FAKTOR INTRAPERSONAL PADA KOMUNIKASI KONFLIK DALAM KELUARGA AKIBAT GAGAL GINJAL KRONIS
}

\author{
Dewanto Putra Fajar', Azizun Kurnia Illahi², \\ Muhammad Irawan Saputra ${ }^{3}$
}

\author{
1)2)3) Universitas Brawijaya \\ dewanto.pf@ub.ac.id
}

$\underline{\text { Received : } 9 \text { February } 2021 \text { | Reviewed: } 31 \text { Mey } 2021 \text { | Accepted: } 23 \text { July } 2021}$

\begin{abstract}
ABSTRAK
Konflik dan komunikasi merupakan kondisi sosial yang secara umum tidak bisa dihindari dan selalu melekat dalam proses komunikasi. Hal itu menjadikan konflik dan komunikasi sebagai proses dinamis dalam interkasi sosial manusia. Menariknya konflik muncul dari berbagai macam penyebab, khusunya yang berasal dari banyak faktor intrapersonal. Penyakit gagal ginjal kronis berpotensi besar menjadi penyebab konflik dalam keluarga, khususnya pada keluarga dengan tingkat resiliensi rendah terhadap konflik. Keadaan demikian memberikan pengaruh besar pada dinamika perubahan faktor intrapersonal, seperti faktor emosional, psikologis, biologis, hingga interaksi sosial keluarga tersebut dengan lingkungan sosialnya. Penelitian ini berusaha menggambarkan aspek konflik dan komunikasi dalam keluarga sebagai akibat penyakit gagal ginjal kronis, dan dinamika faktor intrapersonal berdasarkan perspektif communibiology. Selain itu, penelitian ini melihat dinamika faktor intrapersonal melalui kajian communibiology sebagai upaya mendapatkan solusi dari konflik dalam keluarga yang disebabkan oleh penyakit gagal ginjal kronis. Penelitian ini menggunakan pendekatan metodologis studi kasus untuk mendapatkan gambaran utuh dari konflik dan komunikasi yang terjadi dalam keluarga yang menjadi subyek penelitian. Pada akhirnya penelitian ini berhasil menerapkan kajian communibiology untuk mendapatkan solusi dari konflik dalam keluarga akibat penyakit gagal ginjal kronis, sehingga meminimalisasi konflik.
\end{abstract}

Kata Kunci: Komunikasi keluarga, Konflik, Dinamika Intrapersonal, Communibiology

Korespondensi:

Universitas Brawijaya

Jl. Veteran Malang, Jawa Timur

dewanto.pf@ub.ac.id

JURNAL ILMIAH DINAMIKA SOSIAL 5 (1) 2021 | 55 


\begin{abstract}
Conflict and communication are social conditions that generally cannot be avoided and are always inherent in the communication process. This makes conflict and communication a dynamic process in human social interaction. Interestingly, conflicts arise from various causes, especially those from many intrapersonal factors. Chronic kidney disease has a great potential to be a cause of conflict in the family, especially in families with low levels of resilience to conflict. This situation has a major influence on the dynamics of changing intrapersonal factors, such as emotional, psychological, biological factors, to the social interaction of the family with its social environment. This study attempts to describe aspects of conflict and communication in the family as a result of chronic kidney failure, and the dynamics of intrapersonal factors based on a communicative perspective. In addition, this study looks at the dynamics of intrapersonal factors through communibiology studies as an effort to find solutions to conflicts in the family caused by chronic kidney failure. This research uses a case study methodological approach to get a complete picture of conflict and communication that occurs in the family that is the subject of the study. In the end, this study succeeded in applying the study of communibiology to find solutions to conflicts in the family due to chronic kidney failure, thereby minimize conflic
\end{abstract}

Keywords: Family Communication,Conflict, Intrapersonal Dynamics, Communibiology

\title{
PENDAHULUAN
}

Penyakit gagal ginjal kronis tidak hanya memberikan dampak besar bagi kondisi tubuh penderita, tapi juga memberikan pengaruh pada interaksi sosial individu dengan lingkungannya. Penyakit gagal ginjal kronis memunculkan perubahan pada kondisi intrapersonal dan kondisi interpersonal penderita, sehingga berpotensi memicu konflik interpersonal antara penderita, keluarga penderita, dan lingkungan sosial di sekelilingnya. Pada dasarnya, konflik merupakan bagian yang tidak terpisahkan dari proses komunikasi manusia, namun kemunculan konflik interpersonal akibat kondisi intrapersonal penderita gagal ginjal kronis, menjadi sesuatu yang menarik. Secara umum konflik hampir selalu muncul dalam interaksi sosial manusia, namun dengan tingkat eskalasi yang berbeda, beberapa konflik bisa diselesaikan secara mudah jika eskalasi konflik yang ada relatif kecil, namun beberapa konflik lainnya relatif sulit diselesaikan karena eskalasi konfliknya relatif tinggi. Menariknya banyak faktor intrapersonal dalam diri individu, seperti perbedaan persepsi dan pemahaman tentang penyakit gagal ginjal kronis, hingga perubahan kondisi fisiologis, psikologis, dan emosional penderita gagal ginjal kronis terhadap individu lain, justru meningkatkan potensi konflik. 
Perubahan fisik dan kondisi intrapersonal — kondisi fisiologis_-penderita gagal ginjal kronis akibat komplikasi penyakit, menjadikan individu di sekitar penderita kemungkinan mengucilkan penderita, yang pada akhirnya memunculkan ketegangan dan konflik interpersonal antara penderita dan keluarga penderita, termasuk dengan lingkungan sosialnya. Konflik interpersonal muncul dari satu diantara tiga penyebab utama, yaitu upaya mencapai tujuan yang berbeda; ketidaksepahaman tentang hubungan sosial; dan perbedaan cara individu bersikap dan berperilaku menghadapi situasi dan kondisi sosial (Putnam, 2009). Hal itu menunjukkan bahwa perbedaan cara inidvidu bersikap ketika menghadapi penderita gagal ginjal kronis merupakan penyebab konflik utama yang muncul antara penderita dan keluarga penderita, dengan lingkungan sosialnya.

Konflik akibat penyakit gagal ginjal kronis membawa dampak serius kepada hubungan interpersonal di antara keluarga, dan lingkungan sosialnya. Keluarga informan penelitian menunjukkan bahwa ada penolakan keras dan pengucilan terhadap penderita gagal ginjal kronis, akibat munculnya komplikasi penyakit tersebut, dan perubahan kondisi fisik dan fisiologis penderita akibat penyakit tersebut. Pengucilan dan penghindaran memunculkan ketegangan dan konflik antara penderita dengan lingkungan sosialnya. Kondisi seperti itu dikuatkan pula dengan dorongan sejumlah fortor intrapersonal, yang secara langsung mempengaruhi interaksi interpersonal penderita dengan individu-individu di lingkungan sosialnya (Fajar, 2016). Transimisi emosional-bagian dari faktor intrapersonal-dalam komunikasi interpersonal ikut serta meningkatkan tegangan dan eskalasi konflik, khususnya jika ada perbedaan pemahaman dan pemikiran tentang satu kondisi tertentu (Putnam, 2009), seperti yang terjadi pada kasus gagal ginjal kronis. Kurangnya pemahaman dan informasi memadai tentang gagal ginjal kronis, menjadikan masyarakat awam cenderung menjadikan penderita gagal ginjal kronis sebagai bulan-bulanan hingga cacian. Situasi demikian, berpotensi besar memunculkan konflik interpersonal antara penderita, keluarga penderita, dan lingkungan sosialnya. Hal demikian dikuatkan oleh fakta bahwa konflik yang terjadi antara penderita dan keluarga penderita dengan lingkungan sosialnya ditunjukkan dengan bentuk umpatan, cacian, hinaan terhadap penderita, serta rendahnya dukungan moral dan spiritual dari lingkungan sosial terhadap penderita. Peningkatan eskalasi konflik sendiri kemungkinan besar ikut dipengaruhi oleh dinamika intrapersonal, yang berkaitan erat dengan aspek psikologis, emosional, dan fisiologis, pada masing-masing individu yang terlibat. 
Temuan peneliti di lapangan selama proses penelitian berlangsung menunjukkan bahwa penyakit gagal ginjal kronis kemungkinan besar mengubah-ubah kondisi intrapersonal individu yang terkait dengan peran dan fungsi kondisi fisiologis dan biologis manusia, sehingga mampu mempengaruhi kondisi emosional dan psikologis individu penderita. Padahal perubahan negatif kondisi emosional individu justru meningkatkan ketegangan, yang pada akhirnya meningkatkan eskalasi konflik. Temuan ahli sejumlah ahli fisiologi seperti, Walter Cannon, dan Philip Bard mengajukan pemikirannya bahwa pengalaman-pengalaman emosional mendorong kemunculan ekspresi-ekspresi emosional (Bear et al., 2016). Diagnosis gagal ginjal kronis merupakan pengalaman emosional bagi penderita penyakit tersebut, sehingga semakin besar pula kemungkinan individu mengalami tekanan emosional, ketegangan, hingga berakhir pada konflik. Kondisi demikian dikuatkan oleh pemikiran hasil penelitian Alessandro Tonacci dan koleganya, yaitu bahwa stress muncul dari ketegangan emosional (Tonacci et al., 2019). Setidaknya ada tiga faktor besar yang menjadi penyebab munculnya konflik terkait dengan penyakit gagal ginjal kronis, pertama, penyakit gagal ginjal kronis mempengaruhi kondisi intrapersonal indvidu dengan cara mengubah kondisi fisiologis inidvidu, yang ditunjukkan dengan munculnya komplikasi yang kemungkinan besar perubahan penampilan pada diri penderita; kedua, komplikasi dan perubahan penampilan pada penderita gagal ginjal kronis memunculkan perasaan inferioritas diri penderita terhadap lingkungannya, sehingga penderita merasa dikucilkan oleh lingkungan sosialnya; ketiga, tekanan lingkungan sosial kepada penderita muncul karena rendahnya pengetahuan tentang pengakit gagal ginjal kronis, serta rendahnya penerimaan dan toleransi dari lingkungan sosial terhadap kondisi fisik penderita. Ketiga faktor tersebut menjadi kunci kemunculan konflik antara penderita gagal ginjal kronis dengan lingkungan sosialnya, yang pada akhirnya menunjukkan bahwa konflik interpersonal akibat penyakit tersebut tidak hanya muncul sebagai kondisi sosial, tapi juga kemungkinan besar muncul sebagai kondisi biologis.

Karena itu, perspektif kajian communibiology diharapkan bisa memberikan gambaran komprehensif tentang dinamika intrapersonal yang melingkupi konflik tersebut, serta solusi yang mungkin bisa dirumuskan untuk menyelesaikan konflik tersebut. Perspektif kajian communibiology pada dasarnya bisa digunakan untuk melihat akar dari faktor-faktor intrapersonal individu. Secara lebih detail, perspektif kajian tersebut menunjukkan aspek biologis ikut menjadi bagian dari dinamika intrapersonal di belakang semua perilaku sosial 
manusia, termasuk proses komunikasi (Beatty et al., 2009). Karena itu, dinamikan intrapersonal kemungkinan besar berkaitan erat dengan dinamika faktor-faktor biologis dalam tubuh manusia hingga menuntun pada munculnya perilaku sosial manusia. Sederhananya semua perilaku sosial manusia bisa dicari akar biologisnya. Dengan demikian, ketegangan dan konflik akibat penyakit gagal ginjal kronis kemungkinan besar juga berasal dari faktor intrapersonal, yang secara khusus terkait dengan faktor-faktor biologis. Karena itu peneliti menggunakan pendekatan kajian communibiology sebagai cara untuk mendapatkan penjelasan komprehensif tentang kaitan antara faktor biologis — sebagai bagian dari faktor intrapersonal— dengan proses komunikasi konflik yang terjadi dalam keluarga informan penderita gagal ginjal kronis.

Berdasarkan penjelasan di atas, artikel ini berusaha mendapatkan jawaban komprehensif dan holistik, terkait dengan ketegangan dan konflik akibat penyakit gagal ginjal kronis, berdasarkan sejumlah pertanyaan. 1) Bagaimana perspektif kajian communibiology memandang dinamika faktor intrapersonal pada awal munculnya ketegangan dan konflik dalam keluarga, akibat penyakit gagal ginjal kronis? 2) Bagaimana perspektif kajian communibiology memandang dinamika faktor intrapersonal terkait konflik interpersonal yang terjadi dalam komunikasi keluarga? 3) Bagaimana perspektif kajian communibiology dan kaitannya dengan faktor intrapersonal untuk merumuskan solusi terbaik dari ketegangan dan konflik dalam komunikasi keluarga, akibat penyakit gagal ginjal kronis? Semua pertanyaan di atas bermuara pada satu tujuan besar yang hendak dicapai oleh artikel jurnal ini, yaitu upaya memahami ketegangan konflik dalam proses-proses komunikasi keluarga secara fundamental, yang terkait dengan proses-proses biologis dalam tubuh manusia, sehingga ada solusi terbaik dari ketegangan dan konflik yang dihadapi oleh masing-masing individu dalam keluarga.

\section{KAJIAN TEORI}

Kajian tentang konflik terentang pada sejumlah disiplin ilmu sosial, seperti sosiologi, psikologi, dan juga komunikasi. Dalam kajian komunikasi, konflik pada dasarnya merupakan proses komunikasi yang melibatkan pertentangan tujuan, nilai, dan kepercayaan di antara dua pihak (Oetzel \& Ting-Toomey, 2006). Keadaan demikian membawa beragam pengaruh pada kondisi interaksional individu dengan individu lain. Selain itu, konflik juga muncul dalam banyak ranah sosial, mulai dari ranah keluarga, lingkungan sekitar, hingga konflik sosial 
dengan skala dan eskalasi besar. Pada dasarnya, konflik menjadi bagian dalam proses-proses sosial, termasuk juga proses komunikasi. Anne Maydan Nicotera (Nicotera, 2009) menjelaskan bahwa konflik secara implisit disebabkan oleh dua asumsi dasar, yaitu konflik bermula dari proses komunikasi yang tidak efektif, atau disebabkan oleh upaya membangun superioritas. Dua asumsi tersebut menunjukkan bahwa konflik berpotensi muncul ketika ada proses-proses komunikasi yang kurang efektif, serta tekanan dari individu lain yang berusaha menunjukkan kekuatan dan superioritas.

Rendahnya efektivitas komunikasi yang terjadi antarindividu sangat berpotensi memunculkan malaprofisme - kesalahan penafsiran, sementara malaprofisme itulah yang punya potensi memunculkan konflik, termasuk munculnya bentuk-bentuk agresivitas individu terhadap individu lainnya. Sejumlah pakar psikologi, Elspeth Cameron Ritchie, dan koleganya (Lukey \& Tepe, 2008) memaparkan bahwa agresivitas individu bisa dipicu oleh kondisi fisik dan psikologis. Karena itu, konflik interpersonal bisa muncul karena masing-masing individu yang terlibat menghina kondisi fisik individu lainnya, atau konflik muncul akibat tekanan psikologis pada masing-masing individu yang terlibat. Perubahan kondisi fisik dan fisiologis pada penderita gagal ginjal kronis bisa jadi menjadikan penderita sebagai bahan ejekan atau olok-olok dari lingkungan sekitar. Hal itu jelas memicu munculnya konflik antara penderita gagal ginjal dengan keluarga penderita hingga dengan lingkungan disekitar penderita.

Persepktif kajian communibiology memandang konflik sebagai bagian dari aktivitas proses-proses biologis dalam diri individu. Tekin Kose dan Cansu Oymak (Kose \& Oymak, 2019), dari TED University, Turki, menjelaskan bahwa agresivitas dan konflik berhubungan dengan kesehatan, karena agresivitas mendorong pelemahan kondisi mental dan fisik individu. Temuan dua ilmuwan di atas menguatkan pemikiran bahwa sebagai proses sosial, konflik umumnya selalu melibatkan perubahan pada ciri-ciri fisiologis individu, seperti peningkatan denyut jantung dan nadi, peningkatan irama nafas, serta peningkatan suhu kulit, yang secara umum menandai munculnya ketegangan dan stress (Floyd dan Cole, 2009). Lebih jauh, ketegangan,stress, dan konflik berkaitan erat dengan keadaan mental, emosional, dan kondisi psikologis individu, sebagaimana dijelaskan oleh Eric M. Cooke, dan para koleganya (Cooke et al.,2020). Hal tersebut menunjukkan bahwa konflik tidak hanya dipengaruhi oleh banyak faktor intrapersonal, tapi juga mampu mengubah-ubah kondisi intrapersonal itu sendiri. Karena itu, kita bisa memandang konflik sosial tidak hanya sebagai proses sosial semata, tapi juga hasil 
dari proses biologis, yang secara langsung menjadi bagian dari faktor intrapersonal. Dengan demikian, usaha memahami konflik melalui perspektif biologis-induk dari kajian communibiology — ialah usaha mengkaji konflik dari bagian paling fundamental. Untuk itu peneliti kemungkinan akan menggunakan Teori Cannon-Bard (Cannon-Bard Theory) untuk menjelaskan ketegangan dan stress, yang kemungkinan besar menjadi penyebab munculnya konflik dalam proses-proses interaksi sosial. Teori Cannon-Bard dicetuskan oleh Philip Bard, untuk merevisi pandangan Walter Cannon, teori ini menjelaskan bahwa ada kaitan erat antara ketegangan fisik dengan perubahan-perubahan kondisi fisiologis, begitu pula sebaliknya (Bear et al., 2016). Teori Cannon-Bard secara tidak langsung memberikan landasan penting, bahwa kajian communibiology bisa digunakan untuk memberikan penjelasan spesifik tentang komunikasi dan konflik berdasarkan kaitan antara perilaku dan perubahan kondisi fisiologis.

Pada hakekatnya, semua konflik di semua ranah sosial dan komunikasi muncul dari sebab yang sama dan serupa, yaitu perilaku negatif, perilaku agresif, dan usaha membangun superioritas, yang diwujudakan dalam beragam cara, baik dilakukan secara verbal, atau dilakukan secara fisik. Semua perilaku tersebut merupakan perilaku sosial manusia sebagai individu, yang sejatinya merupakan organisme biologis, yang disusun dari interaksi sistem organ yang sangat rumit. Karena itu, komunikasi dan konflik pasti juga merupakan hasil dari interasi rumit sistem organ di dalam tubuh manusia, sehingga komunikasi dan konflik bisa dijelaskan berdasarkan kajian biologis, yang notabene ikut menyusun perspektif kajian communibiology. Pada akhirnya, konsep-konsep dan pemikiran dalam perspektif kajian communibiology diharapkan bisa menjelaskan dan mendiskripsikan komunikasi dan konflik yang terjadi di lingkungan sosial individu. Pemahaman komprehensif tentang kaitan antara kondisi fisiologis manusia dengan perilaku sosialnya, khusunya yang terkait dengan konflik, diharapkan bisa membantu menemukan solusi efektif terhadap konflik yang terjadi.

\section{METODE PENELITIAN}

Artikel jurnal merupakan hasil dari penelitian kualitatif menggunakan dua pendekatan metodologis, yaitu studi kasus tunggal (single case study) dan pendekatan studi literatur. Kedua pendekatan tersebut digunakan untuk memberikan peneliti pengamatan yang mendalam dan menyeluruh terkait subyek penelitian. Pendekatan studi kasus tunggal memberikan kesempatan 
kepada peneliti untuk melihat secara menyeluruh fenomena sosial kasuistik yang terjadi di masyarakat, dalam hal ini ialah fenomena ketegangan dan konflik akibat penyakit gagal ginjal. Robert E. Stake menjelaskan bahwa studi kasus tunggal merupakan pendekatan motologis yang memungkinkan peneliti mengamati kasus tunggal secara detail (Denzin \& Lincoln, 2005). Pemaparan Stake (2005) memungkinkan peneliti membangun gambaran dan penjelasan detail tentang kasus yang terjadi, khususnya terkait dengan munculnya ketegangan dan konflik akibat munculnya penyakit gagal ginjal. Sementara itu pendekatan studi literatur digunakan oleh peneliti untuk membangun penjelasan komprehensif dan menyeluruh tentang aspek communibiology yang melingkupi ketegangan dan konflik yang terjadi. Studi literatur adalah tahapan kegiatan yang berkaitan dengan metode pengumpulan berbagai data pustaka, pembacaan dan pencatatatan, dan pengelolaan bahan penelitian (Zed, 2008). Studi literatur memberikan kesempatan besar bagi peneliti untuk menjelajahi, menilik, dan meninjau hasil penelitian ilmuwan-ilmuwan lain, konsep-konsep besar yang berkaitan dengan topik penelitian, serta fakta-fakta penting yang tercatat secara rapi dalam literatur-literatur ilmiah, seperti ensiklopedia, jurnal-jurnal ilmiah, buku-buku teks ilmiah, dan literatur-literatur lain yang mendukung. Hal itu dilakukan untuk membangun penjelasan gamblang tentang pendekatan perspektif kajian communibiology, selama penelitian menggunkan radas (peralatan) diagnosis bantu klinis belum bisa dilakukan, karena faktor-faktor tertentu, seperti aksesibilitas pada laboratorium klinis masih rendah, serta biaya penyewaan atau pemilikan alat diagnosis bantu yang mahal.

Penelitian ini menggunakan teknik pengumpulan data secara purposif, yang secara umum memungkinkan peneliti memilih informan secara spesifik berdasarkan kebutuhan peneliti. Karena itu peneliti memilih informan yang menghadapi ketegangan dan konflik akibat ada anggota keluarga yang menderita gagal ginjal. Peneliti menggunakan teknik pengumpulan data melalui proses wawancara mendalam terhadap narasumber. Wawancara mendalam dilakukan peneliti untuk mendapatkan penjelasan detail tentang kasus dan permasalahan yang dihadapi oleh informan. Selain itu wawancara mendalam memberikan kesempatan kepada peneliti untuk memahami fenomena berdasarkan sudut pandang informan, sehingga membantu peneliti membangun penjelasan dan diskripsi yang komprehensif tentang masalah penelitian yang dihadapi. Di samping itu, peneliti juga menggunakan data dari sejumlah literatur, yang bisa 
menjelaskan fenomena dan permasalahan yang terjadi berdasarkan pendekatan perspektif communibiology, termasuk didalamnya perspektif biologi dan fisiologi.

Secara umum peneliti menggunakan teknik analisis yang disesuaikan dengan pendekatan metodologis dalam penelitian ini, yaitu pendekatan studi kasus, dan pendekatan studi literatur. Hal itu menjadikan peneliti menggunakan dua tahap teknik analisis. Tahapan pertama, peneliti melakukan teknik analisis untuk data yang berkaitan dengan aspek studi kasus, dalam konteks ini ialah hasil wawancara mendalam dari kalangan keluarga penderita gagal ginjal kronis. Teknik analisis tersebut dibutuhkan oleh peneliti untuk membangun gambaran dan penjelasan detail tentang ketegangan dan konflik yang muncul di dalam keluarga penderita gagal ginjal. Tahapan kedua, peneliti menggunakan hasil analisis data dari tahapan pertama, untuk kemudian dilakukan teknik analisis data berkaitan dengan studi literatur. Tahapan kedua teknik analisis dalam penelitian ini digunakan untuk menjelaskan semua temuan data berdasarkan kajian communibiology, yang notabene membutuhkan penjelasan mendalam dari studi literartur. Karena itu, teknik analisis, yang digunakan oleh peneliti, dijelaskan dalam sejumlah urutan di bawah ini

\section{Tahapan pertama teknik analisis}

1. Peneliti mengumpulkan data dari informan berupa hasil wawancara mendalam terkait dengan ketegangan dan konflik yang melingkupi keluarga penderita gagal ginjal kronis.

2. Peneliti melakukan refleksi pada semua data hasil wawancara yang dikumpulkan peneliti.

3. Peneliti melakukan analisis data serta membangun penjelasan dan gambaran mendalam tentang permasalahan yang diamati oleh peneliti.

\section{Tahapan kedua teknik analisis}

1. Peneliti menggunakan hasil analisis tahapan pertama untuk digunakan sebagai bagian dari data yang akan dianalisis

2. Peneliti menggunakan studi literatur yang terkait dengan kajian communibiology, fisiologi, dan biologi, untuk menganalisis data yang diperoleh peneliti.

3. Peneliti mendeskripsikan semua temuan data tersebut untuk menjelaskan secara detail, serta membangun jawaban terkait dengan pertanyaan penelitian yang diajukan oleh peneliti. 


\section{PEMBAHASAN \\ Dinamika Intrapersonal pada Awal Munculnya Konflik dalam Keluarga}

Keluarga yang hidup dengan penderita gagal ginjal kronis merupakan keluarga dengan perjuangan tinggi serta tingkat kerentanan konflik yang tinggi. Keluarga tersebut harus mengubah rutinitas kehidupan yang mapan menuju rutinitas kehidupan baru yang penuh perjuangan, baik secara finansial, waktu, serta kebutuhan terhadap pengobatan penderita. Kondisi demikian membawa keluarga penderita kepada ketegangan dan konflik di antara anggota keluarga hingga lingkungan sosial disekitar mereka. Informan-informan dalam penelitian ini menunjukkan bahwa ketegangan selalu muncul dalam keluarga mereka ketika mengetahui bahwa anggota keluarga mereka menderita gagl ginjal kronis. Hal demikian muncul karena semua informan yang diwawancarai menjelaskan bahwa mereka tidak mengetahui seluk-beluk penyakit gagal ginjal kronis, sehingga mereka merasakan ketegangan, dan kecemasaan akibat kurangnya pemahaman terkait penyakit tersebut. Ketegangan dan kecemasan di keluarga informan membahwa keluarga tersebut pada potensi konflik antara anggota keluarga. Perubahan kondisi fisik dan fisiologis penderita menjadikan penderita sebagai bahan ejekan dan olok-olok di kalangan keluarga mereka sendiri, sehingga menghasilkan stress dan tekanan psikologis yang tinggi bagi penderita, dan keluarga penderita. Namun demikian, hal itu kemungkinan tidak berlaku secara umum, karena sebagian informan lainnya, bisa mengatasi ketegangan dan tekanan psikologis tersebut, sehingga mengurangi potensi keluarga tersebut terjebak dalam konflik.

Keluarga SM menjadi keluarga informan dengan tingkat ketegangan dan tekanan psikologis yang tinggi, karena keluarga besarnya menjadikan sang suami-penderita gagal ginjal kronis-sebagai bahan ejekan dan olok-olok, bahkan keluarga besarnya tidak memberikan dukungan dan bantuan secara maksimal bagi keluarga SM. Rendahnya dukungan keluarga besar terhadap keluarga SM, menjadikan keluarga tersebut selalu berada dalam ketegangan hingga masuk dalam ranah konflik dengan keluarga besarnya. Kutipan hasil wawancara dengan keluarga SM menunjukkan hal tersebut. 
Lek masalah dukungan, aku sekarang jadi orang itu jadi seneng labrak mbak. Guduk labrak sing tek...tek...tek ora mbak. Langsung tak lungguhi, biyen aku diem mbak, aku biyen di hina ngono aku diem mbak. Terus kan pak mamat tak tinggal kerja, pak mamat itu ndek rumah sendirian. Lha keadaan e wes drop, dek'e butuh temen, setiap keluar rumah, mesti dilihat. Dilihat perubahan e orang (perubahan fisik pak mamat). Lha HD itu kan pasti ada perubahan fisik e : kulit item, kaki bengkak, rambut rontok. Itu mesti dilihat sama orang. Orang kampung, orang sekitar e.(kutipan wawancara dengan SM)

$* * *$

Pak mamat iku padahal keluar, butuh hiburan dari pada di rumah tapi setiap kali keluar, yang didapat omongan - komentar kaya itu. Terus de'e iku, ngempet, dipendam. Terus pulang, pelampiasan e ke saya. Saya ngomong apa ae gak mempan, pak mamat bilang lek de'e pingin e mati tok. Pokok e minta e de'e mati tok wes. (kutipan wawancara dengan $\mathrm{SM})$

Pernyataan di atas menunjukkan bahwa keluarga SM mengalami ketegangan tinggi, sehingga membawa mereka dalam konflik dengan keluarga besarnya. Rendahnya pemahaman keluarga besar SM terhadap penderita gagal ginjal kronis, menjadikan mereka mengolok-olok penderita gagal ginjal kronis. Padahal tekanan sosial, penghinaan, dan merendahkan harga diri dan kehormatan individu lain bisa menjadi pencetus konflik interpersonal—dalam hal ini terkait dengan penderita gagal ginjal kronis. Dengan kata lain, fluktuasi dan dinamika pada kondisi intrapersonal individu akibat tekanan sosial bisa memicu munculnya konflik interpersonal. Keadaan demikian menjadikan kelaurga SM tidak memiliki banyak kesempatan untuk membangun dukungan kepada sang suami, yang menderita gagal ginjal kronis.

Ketegangan dan konflik di keluarga SM bermula dari rendahnya penerimaan keluarga besar SM terhadap penyakit gagal ginjal kronis yang menimpa suami SM. Rendahnya penerimaan tersebut kemungkinan besar karena komplikasi penyakit gagal ginjal kronis yang menyebabkan perubahan fisik pada suami SM, seperti kulit yang agak menghitam, rambut rontok, dan perubahan fisik lainnya. Keadaan demikian memunculkan perasaan inferior bagi sang suami-penderita gagal ginjal kronis—sekaligus menjadi bahan ejekan bagi keluarga besarnya. Situasi seperti itu memunculkan konflik antara keluarga SM dengan keluarga besarnya, bahkan konflik tersebut memunculkan tekanan besar pada kondisi psikologis keluarga SM, khusunya pada diri sang suami. Pernyataan informan yang menunjukkan bahwa sang suami selalu menyatakan keinginan untuk mati merupakan indikasi penting bahwa ada 
tekanan psikologis dari lingkungan sekitar, yang secara tidak langsung muncul karena penyakit gagal ginjal kronis. Secara psikologis, perasaan ingin mati pada diri individu hadir ketika individu tidak mampu menyalurkan ketegangan psikologisnya pada lingkungan sekitar. Sigmund Freud beranggapan bahwa keingingan untuk mati (death instinct) muncul sebagai upaya individu untuk mencari kedamaian-bebas dari tekanan psikologis - sebagaimana dirasakan oleh individu sebelum lahir (Nevid et al., 2005). Hal itu tercermin pada penderita gagal ginjal kronis yang secara psikologis tidak terlalu mampu melampiaskan emosi kepada lingkungan sekitarnya, yang pada akhirnya membawa individu pada konflik yang serius.

Berdasarkan paparan di atas, kita bisa menyimpulkan bahwa ketegangan dan konflik yang muncul disekitar individu akibat penyakit gagal ginjal kronis umumnya disebabkan oleh tekanan lingkungan sosial yang besar terhadap penderita gagal ginjal kronis, berupa hinaan atau cacian pada penderita, hingga mungkin juga pengucilan. Hal itu muncul karena rendahnya pengetahuan dan pemahaman masyarakat atau lingkungan sosial di sekitar penderita terkait penyakit gagal ginjal kronis, disamping juga fakta bahwa penyakit tersebut juga membawa perubahan pada fisik dan fisiologis penderita, yang menjadikan penderita merasa inferior dengan lingkungan sekitarnya. Tekanan psikologis yang tinggi dari lingkungan tidak didukung oleh kemampuan penderita gagal ginjal kronis untuk memahami dan menerima kondisi diri sendiri. Hal itu meningkatkan munculkan ketegangan psikologis dalam diri individu, yang pada akhirnya meningkatkan eskalasi konflik yang terjadi antara penderita dengan lingkungan sosialnya.

\section{Perspektif Communibiology pada Aspek Intrapersonal dalam Konflik Keluarga}

Perspektif communibiology menjelaskan bahwa ada proses-proses biologis yang melandasi munculnya proses-proses komunikasi manusia (Beatty et al., 2009). Pandangan demikian menjadi argumentasi penting bahwa proses-proses komunikasi manusia dengan lingkungan sosial dilandasi oleh proses-proses biologis. Otak manusia membuat keputusankeputusan dalam proses-proses komunikasi berdasarkan proses perhitungan, pertimbangan rumit yang melibatkan wilayah-wilayah penting dalam otak manusia. Jika demikian maka hal itu berlaku dalam semua proses komunikasi manusia, termasuk juga dalam konflik, yang notabene bagian dari komunikasi. Kemunculan konflik bermula dari ketegangan fisik dan psikologis yang dipicu oleh lingkungan sosial di sekitar individu. Hal demikian berkaitan 
dengan tingkat kemampuan individu menyeimbangkan kondisi pikirannya, rendahnya kemampuan individu menyeimbangkan tekanan dan kondisi pikirannya berkorelasi positif dengan stress, ketegangan, dan kecemasan (Wong, 2010, h 269). Secara sederhana, otak manusia seakan memutuskan bahwa ketegangan dan stress menjadi sesuatu yang paling logis, karena individu diberikan kesempatan untuk bertindak secara agresif melawan penyebab stress dan ketegangan tersebut. Tentu saja, keputusan ini memiliki resiko besar bagi proses-proses komunikasi individu dengan lingkungan sosialnya, namun otak memutuskan untuk mengambil resiko tersebut. Situasi ini kemungkinan besar berlaku pada konflik interpersonal yang muncul akibat dari penyakit gagal ginjal kronis.

Konflik interpersonal yang terjadi di keluarga dengan penderita gagal ginjal kronis memang relatif rumit, karena melibatkan begitu banyak pihak, tidak hanya antara penderita dengan keluarga dan keluarga besarnya, tapi juga terjadi antara anggota keluarga dengan keluarga besarnya. Sederhananya, konflik yang terjadi dibagi menjadi tiga bagian besar, yaitu, konflik antara penderita dengan keluarganya — antara sang suami (MM) dengan istrinya (SM); konflik antara penderita (MM) dengan keluarga besarnya - antara sang suami dengan keluarga besarnya; dan konflik yang terjadi antara istri (SM) dengan keluarga besar suaminya — antara SM dengan keluarga besar sang suami (keluarga besar MM). Semua konflik yang terjadi bermula dari satu penyebab yang sama, yaitu penyakit gagal ginjal kronis yang diderita MM, serta rendahnya pemahaman keluarga besarnya tentang penyakit tersebut. Karena itu penulis akan menjelaskan ketiga proses konflik tersebut berdasarkan kajian communibiology.

Pertama, konflik yang terjadi antara MM dengan SM dimulai ketika sang suami (MM) didiagnosis menderita gagal ginjal kronis. Hal itu merupakan tekanan besar tidak hanya bagi MM tapi juga bagi SM, karena kondisi demikian menggoyahkan struktur keluarga tersebut yang telah mapan. Perubahan drastis dalam keluarga informan terjadi karena MM tidak lagi bisa bekerja dan menafkahi keluarga, karena ia adalah tulang punggung keluarga. Hal demikian mengacaukan struktur keluarga tersebut. Bagi sang suami (MM) diagnosis gagal ginjal yang menimpa dirinya mengubah konfigurasi neurofisiologis dalam otaknya, sehingga memunculkan ketegangan dan kecemasan yang relatif tinggi. Ketegangan dan kecemasan itu berkaitan dengan interpertasi informasi di parietal lobe yang mungkin menyatakan bahwa penyekit gagal ginjal merupakan penyakit degeneratif mematikan yang menjadikan penderitanya menjadi tidak berguna. Pemikiran-pemikiran negatif seperti itu secara langsung 
meningkatkan sekresi hormon cortisol secara berlebihan dan berkepanjangan. Hal itu membawa penderita pada perubahan kondisi intrapersonal individu seperti ketegangan, stress, dan kecemasan berlebihan, yang berpotensi menjadikan penderita memberikan respon agresif pada lingkungan sekitarnya.

Di lain pihak, sang istri (SM) juga mengalami kondisi hampir serupa. Interpertasi dalam otak SM kemungkinan besar menyatakan bahwa ia harus mengeluarkan biaya perawatan yang besar untuk perawatan sang suami (MM) yang menderita gagal ginjal. Padahal SM mengetahui bahwa kondisi finansial mereka mungkin tidak mencukupi untuk hal itu. Keadaan itu menjadikan SM juga merasakan stress, ketegangan, dan kecemasan berlebihan dan berkepanjangan yang menjadikan SM bersikap agresif pada lingkungan sekitarnya. Respon MM dan SM yang sama-sama agresif menjadikan keduanya terlibat konflik dengan eskalasi konflik yang relatif tinggi, bahkan pada beberapa kasus, MM melakukan agresivitas fisik kepada SM. Kutipan wawancara dengan informan menunjukkan hal demikian "soal e setiap kali tak tinggal kerjo, terus aku pulang, pelampiasan e mesti nang aku wes. Sing aku diusirpokok e pelampiasan e lek marah-marah iku nang aku tok." (terj: karena setiap saya pulang kerja, dia selalu melampiaskan kemarahan ke saya. Saya juga pernah diusir, karena selalu saja saya menjadi pelampiasan kemarahannya). Situasi demikian menunjukkan bahwa resiliensi stress yang rendah pada diri MM ditambah dengan sejumlah faktor lain yang mendukung, seperti hanya aspek fisiologis, berpotensi besar membawa individu pada konflik interpersonal.

Kedua, konflik antara MM dengan keluarga besarnya muncul karena perubahan fisik dan fisiolofis pada diri MM akibat gagal ginjal kronis menjadikan dirinya sebagai bahan ejekan dan olok-olok diantara keluarga besarnya. Penerimaan buruk dari keluarga besar meningkatkan tekanan psikologis dan emosinal bagi MM. Keadaan seperti itu menambah ketegangan dan stress yang muncul sehingga menjadikan MM secara tidak langsung terlibat konflik dengan keluarga besarnya. Perubahan fisiologis pada diri MM akibat penyakit gagal ginjal kronis, serta tekanan psikologis serta ketegangan yang tinggi, ditambah dengan munculnya konflik interpersonal antara dirinya dengan keluarga besarnya, kemungkinan besar mempengaruhi konfigurasi fisiologis dalam otak MM, yang mungkin meningkatkan potensi perilaku agresif terhadap lingkungannya. Penelitian yang dilakukan oleh Handan Gunduz-Bruce dan koleganya (Gunduz-Bruce et al., 2019) menunjukkan bahwa tingkat allopregnanolone yang rendah dalam otak mempengaruhi perilaku manusia menjadi lebih agresif. Sederhananya, tingkat agresivitas 
individu sejatinya dipengaruhi oleh sejumlah hormon penting yang saling memberikan pengaruh, seperti peningkatan kadar cortisol dalam darah. Karena dengan analisis jalur diketahui bahwa stress fisik dan psikis kronis menyebabkan tingginya tingkat cortisol yang mempunyai akibat tidak langsung pada jumlah penurunan BAFF (B-Cell Activating Factor) dan IL-21 (Interleukin-21), yang mengendalikan sistem kekebalan tubuh (Mustofa, 2012); tingkat serotonine yang rendah (Nevid et al., 2005); serta turunnya tingkat allopregnanolone (Bruce, et al, 2019). Interaksi dari ketiga komponen hormon di atas secara kemungkinan besar meningkatkan potensi depresi yang pada akhirnya bisa mendorong individu bersikap agresif. Karena itu, ada kemungkinan bahwa ketegangan, stress, serta perilaku agresif yang melibatkan MM, tidak hanya berkaitan dengan tekanan lingkungan sosial yang tinggi, tapi juga berkaitan dengan interaksi ketiga hormon di atas.

Ketiga, konflik antara SM dengan keluarga besar MM, sang suami, merupakan konflik pelik, yang sejatinya merupakan upaya SM membela sang suami (MM) dari tekanan keluarga besar sang suami. Hal itu menjadikan SM secara langsung terlibat dalam konlik dengan keluarga besar MM, yang dianggap tidak memberikan perhatian maksimal pada MM. Karena itu setidaknya ada dua tekanan psikologis besar yang dirasakan oleh SM, yaitu fakta bahwa ia harus merawat sang suami yang sedang sakit, sekaligus mengambil alih tanggungjawab sang suami sebagai tulang punggung keluarga, dan konflik yang melibatkan dirinya dengan keluarga besar sang suami. Ketegangan dan stress yang dirasakan oleh SM kemungkinan besar menjadi faktor pendorong peningkatan eskalasi konflik yang terjadi antara SM dengan keluarga besar sang suami. Keadaan seperti itu kemungkinan menyebabkan perubahan fisiologis dalam diri SM sama seperti perubahan fisiologis dalam diri MM, meskipun disebabkan oleh penyebab yang agak berbeda.

Ketiga ranah konflik yang dihadapi oleh keluarga informan SM, pada dasarnya tidak hanya muncul dari tekanan sosial dan perubahan rutinitas dalam keluarga tersebut, tapi juga muncul sebagai reaksi dari perubahan fisiologis dalam diri masing-masing indvidu yang terlibat dalam konflik tersebut. Perubahan fisiologis dalam diri masing-masing individu dipengaruhi oleh interaksi sejumlah hormon seperti cortisol, serotonin, dan allopregnanolone. Ketidaksimbangan jumlah ketiga hormon tersebut memberikan pengaruh besar pada aspek fisiologis, khusunya neurofisiologis, dalam otak manusia sehingga berpotensi meningkatkan ketegangan, stress, dan perilaku agresif individu terhadap lingkungan sosialnya. Secara 
sederhana, komunikasi dan konflik yang muncul di dalam keluarga SM tidak hanya berasal dari tekanan sosial dan tekanan psikologis semata, tapi juga berasal dari fisiologis, ketidakseimbangan kadar hormon di dalam masing-masing individu yang terlibat.

\section{Perspektif Communibiology sebagai Cara Menemukan Solusi dari Ketergangan dan Konflik}

Ketiga ranah konflik yang dihadapi oleh MM, penderita gagal ginjal kronis, SM sebagai istri dan pendamping penderita gagal kronis, mengindikasikan bahwa faktor fisiologis dan psikologis berperan sama pentingnya dengan faktor-faktor eksternal individu dalam memicu konflik. Teori Cannon-Bard menjelaskan bahwa ketegangan berkaitan erat dengan aktivitas thalamus ketika menghadapi stimulus, sehingga secara fisiologis tubuh individu memberikan respon terhadap informasi dan tekanan yang diterima, sederhananya ada rangkaian berputar (loop) antara stimulus, otak, thalamus, dan tubuh untuk menghasilkan ketegangan dan stress (Bear et al., 2016). Pada konteks gagal ginjal kronis, ketegangan dan stress muncul ketika penderita menemukan fakta bahwa dirinya didiagnosis menderita gagal-ginjal kronis, yang kemudian diinterpertasikan oleh otak penderita sebagai ancaman serius, sehingga pada akhirnya memicu thalamus mengendalikan pengeluaran sejumlah hormon penting yang secara langsung berkorelasi dengan ketegangan dan stress. Ketegangan dan stress yang menimpa penderita gagal ginjal kronis memicu munculnya perilaku kompleks lainnya, yang sejatinya bersifat negatif, seperti misalnya peningkatan potensi perilaku agresif. Meskipun pada dasarnya dampak fisiologis yang dirasakan oleh masing-masing individu relatif sama, namun sejatinya disebabkan oleh stimulus dan informasi yang berbeda. Karena itu, ketegangan dan konflik yang terjadi di masing-masing ranah keluarga MM dan SM, dipicu oleh penyebab relatif berbeda - akan tetapi penyebab utamanya ialah penyakit gagal ginjal kronis, namun menghasilkan dampak fisiologis dan psikologis yang hampir sama.

Secara umum, aspek emosional dalam diri manusia dikendalikan oleh wilayah thalamus, hypothalamus, amygdala, dan hippocampus, yang sejatinya membentuk sistem besar dikenal sebagai limbic system (Carlson, 2015). Teori Cannon-Bard secara filosofis memiliki kemiripan dengan Teori Poros HPA (Hypothalamus-Pituitary-Adrenal (HPA) Axis Theory) Hans Selye, karena keduanya bertumpu pada kaitan antara wilayah emosional dalam otak dengan perilakuperilaku emosional manusia secara umum. Hal demikian memang menarik, karena pada 
kenyataannya limbic system, khususnya pada wilayah thalamus dan hypothalamus memang mengendalikan sekresi sejumlah hormon — secara langsung atau tidak langsung bersama-sama dengan hormon-hormon steroid dari kelenjar adrenal, ikut serta mempengaruhi emosi individu. Karena itu, sekresi serotonin oleh hypothalamus, sekresi cortisol, dan allopregnanolone oleh kelenjar adrenal, kemungkinan besar dikendalikan secara langsung atau tidak langsung oleh limbic system - terutama pada wilayah thalamus dan hypothalamus itu sendiri. Dengan begitu upaya-upaya fisik dan psikologis untuk menyimbangkan kadar hormon dalam tubuh diharapkan bisa menurunkan potensi ketegangan, stress, hingga perilaku agresif dan konflik.

Limbic system merupakan dikenal oleh para ilmuwan sebagai bagian otak paling primitif, karena wilayah itu mengatur fungsi-fungsi dasar manusia, termasuk naluri dan emosi (Parker, 2013). Lebih jauh pengedalian emosional dalam otak individu selalu melibatkan interaksi dari thalamus, hypothalamus, dan kelenjar pituitary, yang secara umum menjadi bagian dari limbic system. Sederhananya, thalamus dan hypothalamus menerima stimulus dari bagian otak tertentu, kemudian meneruskan stimulus tersebut melalui sekresi hormon dan stimulus saraf menuju kelenjar pituitary. Setidaknya ada sekitar tujuh hormon yang disekresikan oleh hypothalamus, termasuk diantaranya ialah CTH-RH (coticotrophin hormon-releasing hormon) yang menstimulasi kelenjar pituitary untuk mensekresikan ACTH (adrenocoticotrophin hormon) untuk kemudian merangsang sekresi hormon-hormon steroid dari kelenjar adrenal (Fajar, 2016). Kelompok hormon-hormon steroid memiliki kemampuan aktif mengubah-ubah kondisi fisiologis termasuk juga kondisi emosional manusia. Kehadiran hormon-hormon steroid, seperti cortisol, dalam dalam manusia meningkatkan tekanan darah, denyut jantung, peningkatan irama pernafasan, sekersi keringat dingin, serta hal-hal lain yang menjadi ciri-ciri utama ketegangan dan kecemasan. Semua ciri-ciri tersebut umumnya juga menjadi penanda umum saat individu melakukan konflik dan agresi kepada individu lainnya. Menariknya, keputusan untuk memulai dan meingkatkan eskalasi ketegangan, konflik, dan tindakan agresif tidak sepenuhnya bersifat naluriah, tapi ditentukan oleh aspek yang lebih tinggi, yaitu aspek kesadaran, niat, dan logika, yang terhimpun di frontal lobe otak, tepatnya pada wilayah prefrontal cortex (Fajar, 2020). Hal itu menunjukkan bahwa secara fisiologis kehadiran konflik tidak hanya dikendalikan oleh aspek endokrinologis (hormon) semata, tapi juga aspek neurologis (saraf). Namun demikian, pada akhirnya, kesadaran dan kepribadian individu-lah 
yang mampu mencegah atau menetralisasi ketegangan dan eskalasi konflik di semua ranah sosial.

Berdasarkan penjelasan dan paparan di atas, peneliti memberikan setidaknya tiga solusi penting untuk mengatasi konflik dalam keluarga, akibat penyakit gagal ginjal kronis, sesuai dengan pandangan pespektif communibiology. Pertama, penderita penyakit gagal ginjal dan keluarga penderita perlu mendapatkan bimbingan konseling, serta layanan pendampingan psikologis. Hal demikian diperlukan karena secara psikologis penderita dan keluarganya membutuhkan dukungan motivasional dari seorang pakar psikologis, sehingga diharapkan bisa menjadi sugesti positif bagi penderita dan keluarganya untuk bisa menghadapi situasi tersebut. Semangat dan sugesti positif diharapkan bisa membantu penderita dan keluarganya untuk selalu berpikir positif, sehingga secara tidak langsung bisa menyeimbangkan kadar hormon dalam tubuh, pada akhirnya mengurangi potensi munculnya ketegangan, konflik, dan perilaku agresif, yang umumnya terjadi dalam konflik. Kedua, kemampuan penderita dan keluarga penderita untuk membangun pikiran positif dengan cara banyak melakukan ibadah sesuai dengan anjuran agama. Hal demikian diharapkan bisa memunculkan semangat, keikhlasan, pikiran-pikiran baik (qona'ah) dan positif bagi penderita dan kelurga penderita. Pikiran postif, semangat, dan keikhlasan secara tidak langsung membantu individu untuk mengurangi potensi munculnya ketegangan, konflik, dan perilaku agresif dalam konflik. Ketiga, upaya pengendalian hormon secara kuratif (pengobatan) kemungkinan juga bisa digunakan untuk membantu penderita dan keluarga penderita untuk menyeimbangkan kadar hormon dalam tubuh dan menekan fungsi-fungsi neurologis yang terkait dengan ketegangan dan konflik. Akan tetapi, aspek kuratif untuk pengendalian hormon harus dilakukan dibawah anjuran dan pengawasan ahli psikiatri (ahli kejiwaan) atau dokter yang berwenang, karena penggunaan obat-obatan bisa berdampak besar bagi keseimbangan fungsi tubuh manusia. Sayangnya, mayoritas penderita gagal ginjal kronis dan keluarga pendamping penderita gagal ginjal kronis cenderung mengabaikan peran penting dari konseling psikologis sekaligus mengabaikan peran penting pikiran positif melalui ibadah. Padahal keduanya relatif mampu membawa perubahan positif bagi penderita gagal ginjal kronis dan keluarga yang mendampingi penderita. Sementara penggunaan obat-obatan harus selalu dibawah pengawasan dokter dan ahli yang kompeten. 


\section{KESIMPULAN}

Penelitian ini menyimpulkan bahwa penyakit gagal ginjal kronis memberikan dampak besar pada penderitanya, dimulai dari munculnya perubahan pada banyak faktor intrapersonal individu, seperti perubahan-perubahan fisiologis, hingga memicu munculnya konflik pada tataran interpersonal. Dengan demikian, konflik interpersonal yang muncul antara keluarga penderita dengan lingkungannya, tidak hanya bisa dianggap sebagai hasil dari proses sosial semata, tapi juga muncul dari proses-proses intrapersonal. Karena itu, kajian communibiology menjelaskan bahwa ketegangan dan konflik hadir sebagai hasil dari interaksi antara otak dengan tubuh individu secara umum melalui interaksi sejumlah hormon, seperti cortisol, serotonin, dan allopregananolone. Pada akhirnya, upaya individu mengendalikan interaksi otak dengan hormon-hormon tersebut melalui pengelolaan faktor-faktor intrapersonal diharapkan bisa mengurangi munculnya ketegangan dan konflik akibat dari penyakit gagal ginjal kronis.

Usaha pengelolaan faktor-faktor intrapersonal bisa dilakukan dengan sejumlah cara baik secara kuratif ataupun psikologis. Pengendalikan emosi secara kuratif bisa dilakukan dengan cara penggunaan obat-obatan antidepresan - dilakukan dibawah pengawasan ahli, sementara pengendalikan emosi secara psikologis dilakukan dengan cara terapi psikologis. Hal itu penting karena saat ini pendampingan psikologis terhadap pasien gagal ginjal kronis relatif jarang dilakukan, padahal pendampingan psikologis terhadap pasien diharapkan bisa membangun sugesti positif bagi pasien agar selalu percaya diri dan bersemangat melakukan perawatan gagal ginjal. Pengendalian emosi secara spiritual dengan cara banyak beribadah sesuai anjuran agama juga bisa digunakan sebagai cara relatif efektif untuk mengurangi munculnya ketegangan, konflik dan perilaku-perilaku agresif. Cara-cara demikian diharapkan bisa menjadi solusi atau setidaknya mengurangi dampak negatif dan potensi ketegangan dan konflik yang muncul akibat dari penyakit gagal ginjal kronis.

\section{DAFTAR PUSTAKA}

Bear, M. F., Connor, B. W., \& Paradiso, M. A. (2016). Neuroscience Exploring The Brain. Fourth edition. Philadelphia: Wolters Kluwers. (4th ed.). Wolters Kluwers.

Beatty, M. J., McCroskey, J. C., \& Pence, M. E. (2009). Communibiological Paradigm (K. Floyd (Ed.)). Hampton Press. 
Carlson, N. R. (2015). Fisiologi Perilaku (11th ed.). Erlangga.

Cooke, E. M., Connolly, E. J., Boisvert, D. L., Armstrong, T. A., Lewis, R. H., Kavish, N., Woeckener, M., Wells, J., \& Harper, J. (2020). Examining How Testosterone and Cortisol Influence the Relationship Between Strain, Negative Emotions, and Antisocial Behavior: A Gendered Analysis. Crime \& Delinquency, 66(10), 1470-1501. https://doi.org/10.1177/0011128720903047

Denzin, N. K., \& Lincoln, Y. S. (Eds.). (2005). The Sage Handbook of Qualitative research. Sage Publications.

Fajar, D. P. (2016). Teori-Teori Komunikasi-Konflik, Upaya Memahami dan Memetakan Konflik. UB Press.

Fajar, D. P. (2020). Pengaruh Negatif Pemberitaan COVID-19 Pada Kondisi Fisiologis Audien (E. N. Shofa \& S. H. Baskara (Eds.)). KBM Indonesia.

Gunduz-Bruce, H., Silber, C., Kaul, I., Rothschild, A. J., Riesenberg, R., Sankoh, A. J., Li, H., Lasser, R., Zorumski, C. F., Rubinow, D. R., Paul, S. M., Jonas, J., Doherty, J. J., \& Kanes, S. J. (2019). Trial of SAGE-217 in Patients with Major Depressive Disorder. New England Journal of Medicine, 381(10), 903-911. https://doi.org/10.1056/NEJMoa1815981

Kose, T., \& Oymak, C. (2019). Exploring Health Effects of Terrorism: A Multi-Level Analysis for Turkey. International Journal of Conflict and Violence, 13. https://doi.org/10.4119/UNIBI/ijcv.654

Lukey, B. J., \& Tepe, V. (Eds.). (2008). Biobehavioral Resilience to Stress (1st ed.). CRC Press. https://doi.org/10.1201/9781420071788

Mustofa, E. (2012). Efek Stres Fisik dan Psikologis pada Kortisol, PGE , BAFF, IL-21, sIgA, dan Candidiasis 2 Vulvovaginal. Jurnal Kedokteran Brawijaya, 27(1), 21-27.

Nevid, J. S., Rathus, S. A., \& Greene, B. (2005). Psikologi Abnormal (M. Medya \& W. C. Kristiaji (Eds.); 5th ed.). Erlangga. 
Nicotera, A. M. (2009). Encyclopedia of Communication Theory (S. W. Littlejohn \& K. A. Foss (Eds.)). Sage Publication.

Oetzel, J. G., \& Ting-Toomey, S. (2006). The Sage Handbook of Conflicy Communication: integrating Theory, Research, and Practice. Sage Publications.

Parker, S. (2013). Ensiklopedia Tubuh Manusia. Erlangga.

Putnam, L. L. (2009). 21st Century Communication, Reference Handbook (W. F. Eadie (Ed.)). Sage Publication.

Tonacci, A., Sansone, F., Pala, A. P., \& Conte, R. (2019). Exhaled breath analysis in evaluation of psychological stress: A short literature review. International Journal of Psychology, 54(5), 589-597. https://doi.org/10.1002/ijop.12494

Zed, M. (2008). Metode Penelitian Kepustakaan. Yayasan Obor Inonesia. 